\title{
Viabilitas dan Vigor Benih Kacang Tanah (Arachis hypogaea L.), Kacang Hijau (Vigna radiata (L.) R. Wilczek), dan Jagung (Zea mays L.) pada Temperatur dan Tekanan Osmotik Berbeda
}

\section{(Viability and Seed Vigour of Peanut (Arachis hypogaea L.), Mung Bean (Vigna radiata (L.) R. Wilczek), and Corn (Zea mays L.) at Different Temperatures and Osmotic Pressures)}

\author{
Zidny Fatikhasari $^{1 *}$, Intani Quarta Lailaty ${ }^{1,2}$, Dian Sartika ${ }^{1}$, Muhammad Aldian Ubaidi ${ }^{1}$ \\ (Diterima Oktober 2021/Disetujui Desember 2021)
}

\begin{abstract}
ABSTRAK
Viabilitas dan vigor merupakan komponen penilaian kualitas benih yang dipengaruhi oleh faktor internal maupun eksternal benih, seperti salinitas dan temperatur. Salinitas berhubungan dengan interaksi antara tekanan osmotik dan perkecambahan benih. Pada penelitian ini digunakan 3 jenis benih, yaitu kacang tanah (Arachis hypogaea L.), kacang hijau (Vigna radiata (L.) R. Wilczek), dan jagung (Zea mays L.). Tujuan penelitian adalah untuk mengevaluasi viabilitas benih menggunakan Triphenyl Tetrazolium Chloride (TTC) dan menganalisis pengaruh tekanan osmotik dan temperatur yang berbeda pada viabilitas dan vigor ketiga benih. Uji viabilitas benih kacang tanah dilakukan dengan menggunakan larutan TTC 1\%. Pengujian pengaruh tekanan osmotik pada viabilitas dan vigor benih dilakukan dengan menggunakan variasi konsentrasi $\mathrm{NaCl}(0,01 \mathrm{M} ; 0,05 \mathrm{M} ; 0,5 \mathrm{M} ; 0,1 \mathrm{M} ; 1 \mathrm{M})$. Uji perkecambahan ketiga benih dilakukan dengan menggunakan temperatur $30^{\circ} \mathrm{C}$ dan $35^{\circ} \mathrm{C}$, masing-masing dengan tiga ulangan. Parameter uji meliputi daya kecambah, laju perkecambahan (LP), Indeks Kecepatan Perkecambahan (IKP), Indeks Vigor (IV), keserempakan tumbuh, dan kecepatan tumbuh benih. Hasil penelitian menunjukkan bahwa larutan TTC efektif digunakan untuk menguji viabilitas benih. Kacang hijau memiliki daya kecambah, LP, IKP, IV, keserempakan tumbuh, dan kecepatan tumbuh benih yang paling tinggi dibandingkan benih uji lainnya pada semua perlakuan salinitas dan temperatur. Perlakuan temperatur $30^{\circ} \mathrm{C}$ menghasilkan viabilitas dan vigor benih paling baik untuk ketiga tanaman uji. Perlakuan temperatur dan salinitas berpengaruh pada kualitas ketiga benih tanaman yang selanjutnya dapat digunakan sebagai penentuan kualitas benih kacang tanah, kacang hijau, dan jagung.
\end{abstract}

Kata kunci: daya kecambah, salinitas, Triphenyl tetrazolium chloride, viabilitas, vigor

\section{ABSTRACT}

Viability and vigor are components of seed quality assessment which are influenced by internal and external factors of the seed, i.e., salinity and temperature. Salinity is related to the interaction between osmotic pressure and seed germination. This study used 3 types of seeds, they are peanuts (Arachis hypogaea L.), mung bean (Vigna radiata (L.) R. Wilczek), and corn (Zea mays L.). The purposes of this study were to determine seed viability by using Triphenyl Tetrazolium Chloride (TTC), to analyze the effects of different osmotic pressures and temperatures on seed viability and vigor. Peanut seed viability test was conducted by using $1 \%$ TTC solution. Testing the effect of osmotic pressure on seed viability and vigor was conducted by using various concentrations of $\mathrm{NaCl}(0.01 \mathrm{M} ; 0.05 \mathrm{M} ; 0.5 \mathrm{M}$; $0.1 \mathrm{M} ; 1 \mathrm{M}$ ). The germination test of the three seeds was conducted by using temperatures of $30^{\circ} \mathrm{C}$ and $35^{\circ} \mathrm{C}$, each with three replications. The test parameters measured included germination, germination rate, germination speed index, vigor index, simultaneous growth, and the speed of seed growth. The results showed that TTC solution was effectively used to determine seed viability. Mung bean had the highest germination rate, LP, IKP, IV, simultaneous growth, and speed of seed growth compared to the other tested seeds in all salinity and temperature treatments. The $30^{\circ} \mathrm{C}$ temperature treatment resulted in the best viability and seed vigor for the three tested plants. Treatments of temperature and salinity affect the quality of the three plant seeds which can then be used to determine the quality of peanut, mung bean, and corn seeds.

Keywords: germination, salinity, triphenyl tetrazolium chloride, viability, vigour

\footnotetext{
1 Fakultas Biologi, Universitas Gadjah Mada, Jl. Teknika Selatan Sekip Utara, Yogyakarta 55281

2 Pusat Riset Konservasi Tumbuhan dan Kebun Raya, Badan Riset dan Inovasi Nasional, Jl. Kebun Raya Cibodas, Cianjur 43253

* Penulis Korespondensi:

Email: fatikhazidny@yahoo.co.id
}

\section{PENDAHULUAN}

Pertanian merupakan aktivitas penting yang dapat mendukung perekonomian seiring dengan peningkatan jumlah penduduk, khususnya di negara-negara berkembang. Peningkatan jumlah penduduk Indonesia berkorelasi positif dengan ketersediaan pangan. 
Sebagian besar tanaman pangan dihasilkan dari benih sehingga kualitas benih sangat penting untuk menentukan keberhasilan produksi hasil panen (Grzybowski et al. 2012). Mutu benih merupakan awal dari keberhasilan suatu proses produksi serta berkaitan erat dengan viabilitas dan vigor benih. Raganatha et al. (2014) melaporkan bahwa apabila vigor awal benih tidak dapat dipertahankan maka benih yang disimpan akan selalu mengalami proses kemunduran mutu selama penyimpanan. Sifat kemunduran benih dapat ditandai secara fisiologis dan biokimiawi. Penurunan indeks vigor dan daya kecambah merupakan indikasi fisiologis penurunan mutu benih. Sementara itu, indikasi secara biokimiawi adalah penurunan aktivitas enzim, penurunan cadangan makanan, dan peningkatan nilai konduktivitas (Tatipata et al. 2004). Sifat kemunduran mutu suatu benih tidak dapat diperbaiki atau dicegah, namun dapat diperkecil dengan melakukan pengolahan dan penyimpanan secara tepat, terutama kondisi kadar air benih dan keadaan lingkungan, seperti kelembapan dan temperatur.

Sebelum menjadi tanaman, benih harus melalui proses perkecambahan terlebih dahulu. Tekanan lingkungan abiotik seperti kekeringan, salinitas, dan temperatur merupakan penyebab utama keterbatasan benih untuk berkecambah. Selain itu, faktor lingkungan tersebut juga mampu menyebabkan dormansi benih dan menurunkan viabilitas benih (Nisa et al. 2007). Temperatur tinggi selama penyimpanan benih juga berkontribusi pada kerusakan benih lebih lanjut dengan menginisiasi perubahan degeneratif, seperti distabilisasi aktivitas enzim dan kehilangan integritas membran sel (Moriya et al. 2015).

Pengujian kualitas benih ini sangat penting dan harus mendapatkan perhatian khusus. Menjaga kualitas benih bertujuan memberikan jaminan kepada para petani untuk mendapatkan benih dengan kualitas yang sesuai dengan Standar Nasional Indonesia (SNI) sehingga pada akhirnya dapat menekan angka kerugian yang disebabkan oleh kualitas benih yang buruk di awal penanaman. Dengan adanya kendala di lapangan terkait dengan kualitas benih maka penting dilakukan metode pengujian benih untuk mengevaluasi viabilitas benih secara tepat dan cepat. Pengujian benih dapat dilakukan dengan indikasi langsung dan indikasi tidak langsung. Menurut Fatmawati et al. (2018), metode langsung indikasi langsung, seperti uji daya kecambah untuk mengetahui persentase benih yang berkecambah normal, sedangkan metode langsung indikasi tidak langsung, seperti uji tetrazolium untuk mengetahui persentase benih hidup dan tak hidup serta benih dorman.

Berdasarkan uraian permasalahan tekanan lingkungan yang dapat memengaruhi viabilitas dan vigor benih maka perlu dilakukan pengujian kualitas benih. Salah satu metode uji yang digunakan ialah uji menggunakan Triphenyl Tetrazolium Chloride (TTC). Uji TTC merupakan uji viabilitas benih untuk mengetahui apakah suatu benih masih dalam kondisi hidup atau sudah mati berdasarkan pengukuran aktivitas respirasi dengan bantuan enzim dehidrogenase (Copeland \& McDonald 2001). Masingmasing benih memiliki karakteristik dan tipe perkecambahan yang berbeda-beda. Pada penelitian ini digunakan tiga jenis benih tanaman, yaitu kacang tanah (Arachis hypogaea L.), kacang hijau (Vigna radiata (L.) $R$. Wilczek), dan jagung (Zea mays L.) yang termasuk ke dalam kelompok bahan pangan utama di Indonesia. Oleh karena itu, penelitian ini bertujuan untuk mengetahui viabilitas benih dengan menggunakan Triphenyl Tetrazolium Chloride (TTC), serta menganalisis pengaruh tekanan osmotik dan temperatur yang berbeda pada viabilitas dan vigor benih kacang tanah ( $A$. hypogaea L.), kacang hijau ( $V$. radiata $L$.), dan jagung ( $Z$. mays $L$.)

\section{METODE PENELITIAN}

Penelitian dilakukan di Laboratorium Fisiologi Tumbuhan, Universitas Gadjah Mada, Yogyakarta. Bahan yang digunakan adalah benih kacang tanah (Arachis hypogaea L.), kacang hijau (Vigna radiata (L.) R. Wilczek), dan jagung (Zea mays L.) untuk pengujian viabilitas dan vigor dengan perlakuan tekanan osmotik dan temperatur yang berbeda. Masing-masing perlakuan menggunakan 10 benih dengan 3 ulangan.

\section{Prosedur Penelitian \\ Uji Viabilitas dengan Triphenyl Tetrazolium Chloride}

Benih kacang tanah ( $A$. hypogaea L.) dibagi menjadi dua kelompok masing-masing 10 benih. Kelompok 1 direndam dalam akuades, dikupas kulit arinya, dan dibelah menjadi 20 kotiledon. Kelompok 2 direbus ke dalam air mendidih, kemudian dicuci, dikupas kulit arinya, dan dibelah menjadi 20 kotiledon. Benih kelompok 1 dan 2 masing-masing diletakkan di cawan petri dan dituangi larutan tetrazolium $1 \%$. Selanjutnya, cawan petri kelompok 1 dan 2 dimasukkan ke dalam oven suhu $30^{\circ} \mathrm{C}$ selama 15 menit, kemudian diangkat dan diamati perubahan warnanya.

\section{Uji Germinasi Benih pada Variasi Tekanan Osmotik}

Percobaan uji germinasi benih pada variasi tekanan osmotik menggunakan tiga jenis benih, yaitu benih kacang hijau (V. radiata (L.) R. Wilczek), kacang tanah (A. hypogaea L.), dan jagung (Z. mays L.). Media tanam yang digunakan adalah bata merah yang sudah dihaluskan. Bata merah disiapkan dalam cawan petri dan dibasahi dengan larutan $\mathrm{NaCl}(0,01 \mathrm{M} ; 0,05 \mathrm{M} ; 0,1$ $\mathrm{M}$; 0,5 M; dan $1 \mathrm{M}$ ) masing-masing sebanyak $20 \mathrm{~mL}$. Ketiga jenis benih dikecambahkan pada cawan petri sebanyak 3 ulangan, masing-masing 10 benih. Pengamatan germinasi benih dilakukan setiap hari selama 7 hari setelah tanam (HST). 


\section{Uji Germinasi Benih pada Variasi Temperatur}

Uji germinasi benih pada variasi temperatur dilakukan dengan menggunakan tiga jenis benih, yaitu benih kacang hijau (V. radiata (L.) R.Wilczek), benih kacang tanah (A. hypogaea L.), dan benih jagung (Zea mays L.) yang masing-masing disiapkan sebanyak 10 benih dan dikecambahkan di cawan petri dengan media kapas. Dilakukan dua perlakuan, yaitu inkubasi pada temperatur $30^{\circ} \mathrm{C}$ (suhu ruang) dan $35^{\circ} \mathrm{C}$ (suhu oven) masing-masing perlakuan menggunakan 3 ulangan. Pengamatan germinasi benih dilakukan setiap hari selama $7 \mathrm{HST}$.

\section{Analisis Data Parameter Viabilitas Daya kecambah (\%)}

Pengamatan dilakukan pada benih yang telah berkecambah normal pada pengamatan ke-1 (hari ke1) sampai pengamatan ke-7 (hari ke-7) setelah tanam. Penghitungan daya kecambah pada ketiga benih tanaman dilakukan dengan menggunakan rumus ISTA (2010) sebagai berikut:

$$
\mathrm{DK}=\frac{\mathrm{JK}}{J C} \times 100 \%
$$

Keterangan:

$\mathrm{DK}=$ Daya kecambah

$\mathrm{JK}=$ Jumlah kecambah normal

$\mathrm{J}=$ Jumlah benih yang dikecambahkan

\section{Laju Perkecambahan (Hari)}

Pengamatan laju perkecambahan (LP) menunjukkan kemampuan benih untuk berkecambah secara cepat pada kisaran waktu tertentu. LP ditentukan dengan menghitung jumlah hari yang diperlukan untuk munculnya radikula dan plumula. Laju perkecambahan dihitung dengan menggunakan rumus Sutopo (1988):

$$
L P=\frac{\mathrm{N} 1 \mathrm{~T} 1+\mathrm{N} 2 \mathrm{~T} 2+\cdots+\mathrm{NxTx}}{\mathrm{JB}}
$$

Keterangan:

$\mathrm{LP}=$ Laju perkecambahan

$\mathrm{N}=$ Jumlah benih yang berkecambah

$\mathrm{T}$ = Jumlah waktu antara pengujian awal sampai pengujian akhir pada interval tertentu suatu pengamatan (N1T1 hingga N7T7)

$\mathrm{JB}=$ Jumlah benih yang berkecambah

\section{Indeks Kecepatan Perkecambahan (IKP)}

Indeks kecepatan perkecambahan berkorelasi dengan LP yang didukung oleh nilai daya kecambah dari setiap benih yang mempunyai viabilitas yang tinggi. IKP dihitung selama 7 hari pengamatan pada ketiga benih dengan menggunakan rumus Copeland \& McDonald (2001):

$$
\mathrm{IKP}=\frac{G 1}{D 1}+\frac{G 2}{D 2}+\frac{G 3}{D 3}+\cdots \frac{\mathrm{Gn}}{D n}
$$

Keterangan:

IKP = Indeks kecepatan perkecambahan

$G$ = Jumlah benih yang berkecambah

$\mathrm{D}=$ Waktu yang bersesuaian dengan jumlah tersebut

$\mathrm{N}=$ Jumlah hari pada perhitungan akhir

\section{Analisis Data Parameter Vigor \\ Indeks Vigor (IV) (\%)}

Sifat vigor benih mengindikasikan kemampuan benih untuk mampu tumbuh secara cepat, normal, dan seragam. Pengamatan indeks vigor dilakukan pada jumlah kecambah normal pada hitungan pertama, yaitu hari ke- 5 menurut ISTA (2010):

$$
\mathrm{IV}=\frac{\text { Jumlah kecambah pada hitungan pertama }}{\text { jumlah benih yang ditanam }} \times 100 \%
$$

\section{Keserempakan Tumbuh Benih $\left(\mathrm{K}_{\mathrm{st}}\right)(\%)$}

Keserempakan tumbuh benih dihitung berdasarkan persentase kecambah normal kuat pada 6 hari setelah tanam (HST). Penghitungan pada benih untuk keserempakan tumbuh benih kacang hijau, kacang tanah, dan jagung dilakukan pada hari ke-6. Keserempakan tumbuh benih dihitung dengan rumus menurut Tefa (2017):

$$
\mathrm{K} s t=\frac{\mathrm{KK}}{\mathrm{TB}} \times 100 \%
$$

Keterangan:

$\mathrm{KST}=$ Keserempakan tumbuh

$\mathrm{KK}=$ Jumlah biji yang berkecambah pada hari ke- 6

TB = Jumlah biji yang dikecambahkan

\section{Kecepatan Tumbuh Benih (Kct) (\%/etmal)}

Kecepatan tumbuh benih mengindikasikan kekuatan vigor tumbuh benih yang kuat dan mampu bertahan pada kondisi lingkungan yang suboptimal. Kecepatan tumbuh benih dihitung setiap hari selama 7 hari pada benih yang tumbuh normal. Kecepatan tumbuh benih dihitung dengan rumus menurut Tefa (2017):

$$
\mathrm{K}_{C T}=\left(\% \frac{\mathrm{KN}}{\text { etmal }}\right)=\sum_{0}^{n} \frac{N}{t}
$$

Keterangan:

$\mathrm{N} / \mathrm{t} 1=$ Pesentase biji berkecambah dibagi waktu

(24jam), hari ke-2 (48 jam) dan seterusnya 1 etmal $=1$ hari

\section{HASIL DAN PEMBAHASAN}

\section{Viabilitas Benih}

Viabilitas merupakan daya hidup benih yang dapat menunjukkan proses pertumbuhan benih. Parameter viabilitas yang diamati dalam penelitian ini ialah daya kecambah, laju perkecambahan, indeks kecepatan berkecambah, dan uji viabilitas menggunakan larutan tetrazolium. 


\section{Uji Viabilitas Menggunakan Triphenyl Tetrazolium Chloride}

Pengujian menggunakan tetrazolium merupakan uji biokimia untuk mengetahui viabilitas suatu benih secara cepat. Berbagai keuntungan menggunakan metode uji cepat ini, antara lain dapat mengetahui viabilitas benih secara cepat, terutama pada benih dengan dormansi panjang atau benih dengan perkecambahan yang lambat. Uji TTC diperlukan untuk identifikasi potensi perkecambahan dalam waktu singkat. Selain itu, menurut ISTA (2010), uji TTC juga digunakan untuk menetapkan viabilitas individu benih pada akhir pengujian perkecambahan, khususnya untuk benih dengan dormansi dan berbagai tipe kerusakan panen atau kerusakan akibat pemprosesan benih, seperti kerusakan karena pemanasan, kerusakan mekanis, maupun kerusakan karena serangga. Berdasarkan hasil penelitian, didapatkan perbedaan antara benih kacang tanah yang diberi perlakuan direbus dan tidak direbus, seperti yang disajikan pada Gambar 1. Hasil uji menggunakan larutan tetrazolium menunjukkan bahwa kacang tanah yang direbus tidak mengalami perubahan warna (tetap berwarna putih), sedangkan kacang tanah yang tidak direbus terlebih dahulu mengalami perubahan warna menjadi merah. Hal ini menunjukkan bahwa kacang tanah tanpa pemanasan masih memiliki daya viabilitas yang tinggi. Benih kacang tanah yang diberi perlakuan dengan pemanasan menunjukkan warna putih setelah diuji dengan larutan tetrazolium. Hal ini disebabkan karena embrio benih kacang tanah tersebut telah mati akibat pemanasan. Kematian benih dibuktikan dengan tidak terjadinya respirasi seperti pada sel-sel yang masih hidup (Gambar 2).

Uji tetrazolium merupakan salah satu teknik yang dapat digunakan untuk membuktikan bahwa benih masih dalam kondisi baik atau sudah rusak (Satya et al. 2015) sehingga ketika ada kebutuhan akan benih yang cepat, uji tetrazolium adalah yang paling tepat. Uji tetrazolium secara tidak langsung menentukan aktivitas respirasi dalam sel, yang bergantung pada aktivitas enzim dehidrogenase. Semakin tinggi aktivitas respirasi di dalam sel, maka kecerahan warna merah yang terbentuk akan semakin terang. Hal ini mengindikasikan bahwa jaringan benih masih hidup. Laju respirasi dipengaruhi oleh beberapa faktor, seperti daya imbibisi benih pada saat direndam dalam larutan, konsentrasi $\mathrm{CO}_{2}$ dan $\mathrm{O}_{2}$, dormansi, umur benih, keadaan embrio, serta komposisi kimia benih (Hasrawati et al. 2015).

Garam tetrazolium (2,4,5 triphenyl tetrazolium chloride) sebagai suatu "oxidation reduction indicator" oleh aksi enzim dehidrogenase diubah dari bentuk oksidasi tak berwarna, terlarut menjadi berubah sifat berwarna merah, stabil, tidak terlarut yang disebut dengan triphenylformazan atau formazan (Isely 1985 dalam Subantoro \& Prabowo 2013). Pada saat benih direndam dalam larutan tetrazolim, selanjutnya larutan akan diimbibisi oleh jaringan meristematik dalam embrio yang akan mengganggu proses reduksi sel

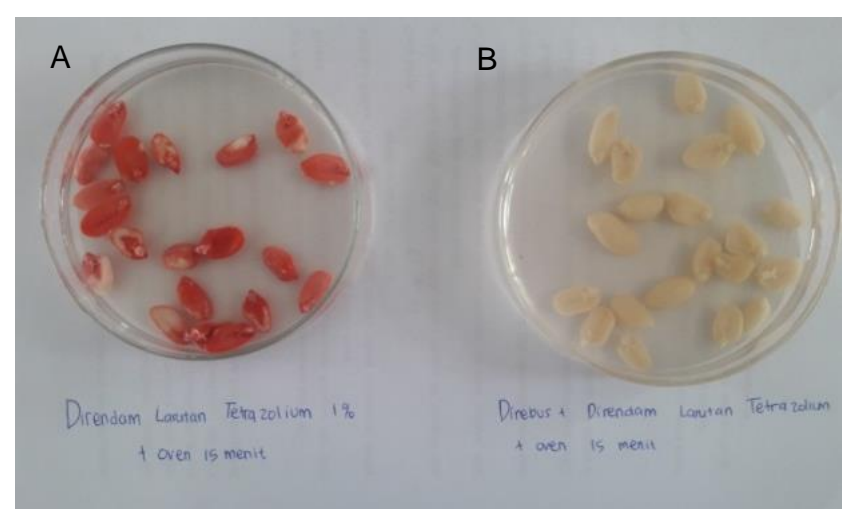

Gambar 1 Hasil uji viabilitas benih kacang tanah dengan larutan tetrazolium, (A) tanpa direbus dan (B) direbus.

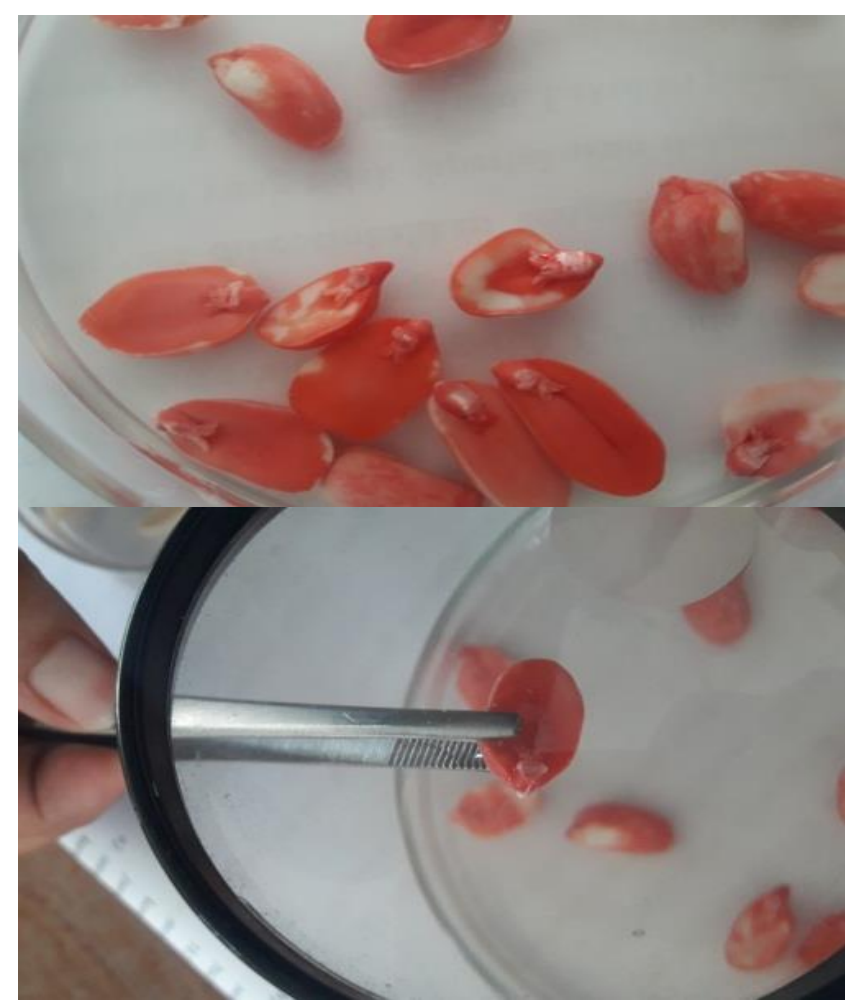

Gambar 2 Detail kacang tanah tanpa direbus setelah diuji dengan larutan tetrazolium.

hidup dengan menerima ion hidrogen yang dilepaskan dari proses respirasi. Dalam keadaan tereduksi, tetrazolium sifatnya tidak terlarut dan stabil di dalam sel yang memberikan warna merah pada sel (Copeland \& Mcdonald 1976; Subantoro \& Prabowo 2013; Neto \& Krzyzanowski 2019).

Dari hasil penelitian pada Gambar 2 menunjukkan perubahan warna merah pada benih kacang tanah setelah direndam dengan larutan tetrazolium, baik pada kotiledon dan daun lembaga. Penelitian Subantoro \& Prabowo (2013) melaporkan bahwa pembentukan warna merah pada benih jagung dan kedelai terjadi akibat perlakuan tetrazolium. Hasil menunjukkan bahwa kedua benih masih dalam kondisi yang sehat, kotiledon dan embrionya berwarna merah, dan benih tumbuh dengan baik dengan kecepatan 
yang relatif tinggi. Hal ini diasumsikan bahwa ketiga jenis benih yang digunakan pada penelitian ini juga dalam kondisi baik.

\section{Daya Kecambah}

Kemampuan berkecambah tiap jenis benih berbeda-beda dan dipengaruhi oleh faktor internal maupun eksternal benih. Pada penelitian ini, temperatur dan salinitas memengaruhi daya kecambah ketiga jenis benih. Berdasarkan data yang disajikan pada Tabel 1 terlihat bahwa konsentrasi $\mathrm{NaCl}$ berpengaruh pada daya kecambah untuk setiap jenis benih. Persentase daya kecambah benih semakin menurun seiring dengan peningkatan konsentrasi $\mathrm{NaCl}$ dan berlaku untuk semua jenis benih. Daya kecambah paling tinggi dihasilkan oleh benih kacang tanah dan benih jagung pada perlakuan $0,01 \mathrm{M} \mathrm{NaCl}$, berturutturut sebesar $70 \%$ dan $76 \%$. Persentase tersebut semakin menurun seiring dengan kenaikan konsentrasi $\mathrm{NaCl}$. Perlakuan penambahan $\mathrm{NaCl}$ pada media meningkatkan salinitas substrat perkecambahan. Semakin kecil ukuran benih akan lebih rentan terhadap lingkungan sekitar, khususnya substrat. Apabila dibandingkan dengan air, larutan garam memiliki unsur yang lebih pekat sehingga semakin tinggi konsentrasi larutan garam maka akan semakin pekat, yang mengakibatkan benih semakin sulit untuk menyerap larutan $\mathrm{NaCl}$ sehingga jaringan akar tidak berkembang karena hormon auksin sebagai hormon utama pengatur perkembangan akar menjadi tidak aktif (Da Costa 2019). Larutan dengan osmotik yang tinggi tidak dapat diserap oleh benih sehingga imbibisi tidak dapat terjadi dan perkecambahan menjadi terhambat.

Dari Tabel 1 dapat diketahui bahwa daya kecambah semakin berkurang pada semua jenis benih seiring dengan peningkatan suhu. Suhu $30^{\circ} \mathrm{C}$ adalah suhu yang optimal untuk perkecambahan benih kacang hijau, kacang tanah, dan jagung. Hal ini dibuktikan dengan persentase perkecambahan yang tinggi hingga $100 \%$. Suhu lebih dari $30^{\circ} \mathrm{C}$ dianggap sebagai cekaman lingkungan bagi benih, akibatnya benih mengalami hambatan untuk berkecambah, yang dibuktikan dengan total perkecambahan benih jagung yang diberikan suhu $35^{\circ} \mathrm{C}$ adalah $10 \%$, benih kacang hijau $70 \%$, dan benih kacang tanah $46 \%$.

Faktor suhu berkaitan erat dengan faktor pembatas dalam pertumbuhan dan perkembangan tanaman. Benih tanaman memerlukan suhu optimum untuk dapat berkecambah dengan baik. Suhu yang diperlukan dalam pertumbuhan dan perkembangan tanaman disebut suhu kardinal yang meliputi suhu optimum $\left(34^{\circ} \mathrm{C}\right)$, suhu minimum $\left(10^{\circ} \mathrm{C}\right)$, dan suhu maksimum $\left(45^{\circ} \mathrm{C}\right)$ (Bouzo 2012). Benih mengalami daya kecambah tinggi pada saat suhu mendekati optimum, dan setiap benih memiliki suhu optimum yang berbeda. Pada benih kacang hijau, kacang tanah, dan jagung, suhu $35^{\circ} \mathrm{C}$ bukan suhu optimum sehingga beberapa benih masih tetap dapat berkecambah, namun daya kecambahnya berkurang dan tidak sebesar daya kecambah pada suhu $30^{\circ} \mathrm{C}$. Suhu yang sesuai berpengaruh pada kadar HSP (Heatshock Protein) dan HSP akan berpengaruh pada tinggi rendahnya vigor benih (Guan et al. 2020).

Menurut Tsegay \& Gebreslassie (2014) imbibisi air ke dalam benih merupakan awal mula dari perkecambahan benih. Beberapa faktor yang memengaruhi imbibisi air ke dalam benih, antara lain komposisi benih, impermeabilitas lapisan luar benih, dan ketersediaan air. Ketersediaan air untuk imbibisi bergantung pada potensial air sel. Potensial air sel tersebut merupakan hasil dari tekanan matriks dinding sel, konsentrasi osmotik sel, dan tekanan turgor sel. Fenomena ini dapat terjadi karena salinitas menurunkan potensi osmotik tanah larutan dan menunda hidrasi benih. Pada saat suhu meningkat, waktu perkecambahan menjadi berkurang (Delgado et al. 2016).

\section{Laju Perkecambahan}

Menghitung laju perkecambahan dapat digunakan untuk mengetahui uji yang tepat untuk meningkatkan daya perkecambahan benih. Berdasarkan hasil pengamatan pemberian variasi tekanan osmotik pada benih Arachis hypogaea L., Vigna radiata (L.) $R$. Wilczek, dan Zea mays L. didapatkan hasil berupa persentase germinasi benih selama tujuh hari tanam yang disajikan pada Gambar 3. Persentase germinasi benih pada Gambar 3 menunjukkan bahwa pemberian $\mathrm{NaCl} 1 \mathrm{M}$ menghambat germinasi ketiga jenis benih. $\mathrm{NaCl}$ dapat menghambat laju perkecambahan, Semakin pekat $\mathrm{NaCl}$ semakin tinggi tingkat osmotiknya dan salinitas yang berlebih berpengaruh pada beberapa fungsi fisiologis, seperti respirasi, fotosintesis, fiksasi nitrogen, dan metabolisme karbohidrat, dan garam yang terakumulasi di sitosol akan merusak fungsi fisiologis di tingkat sel (Jacob et al. 2020).

Tabel 1 Daya kecambah benih kacang hijau ( $V$. radiata), kacang tanah ( $A$. hypogaea), dan jagung ( $Z$. mays) pada berbagai perlakuan konsentrasi $\mathrm{NaCl}$ selama 7 hari pengamatan

\begin{tabular}{lcccc}
\hline \multirow{2}{*}{ Perlakuan } & & \multicolumn{3}{c}{ Daya kecambah (\%) } \\
\cline { 3 - 5 } & 0,01 & Kacang hijau & Kacang tanah & Jagung \\
\hline \multirow{2}{*}{$\mathrm{NaCl}(\mathrm{M})$} & 0,05 & 9,33 & 70,00 & 76,67 \\
& 0,10 & 90,00 & 56,67 & 63,33 \\
& 0,50 & 93,33 & 53,33 & 56,67 \\
Temperatur $\left({ }^{\circ} \mathrm{C}\right)$ & 1,00 & 96,67 & 6,67 & 3,33 \\
& 30,00 & 0,00 & 3,33 & 0,00 \\
\hline
\end{tabular}



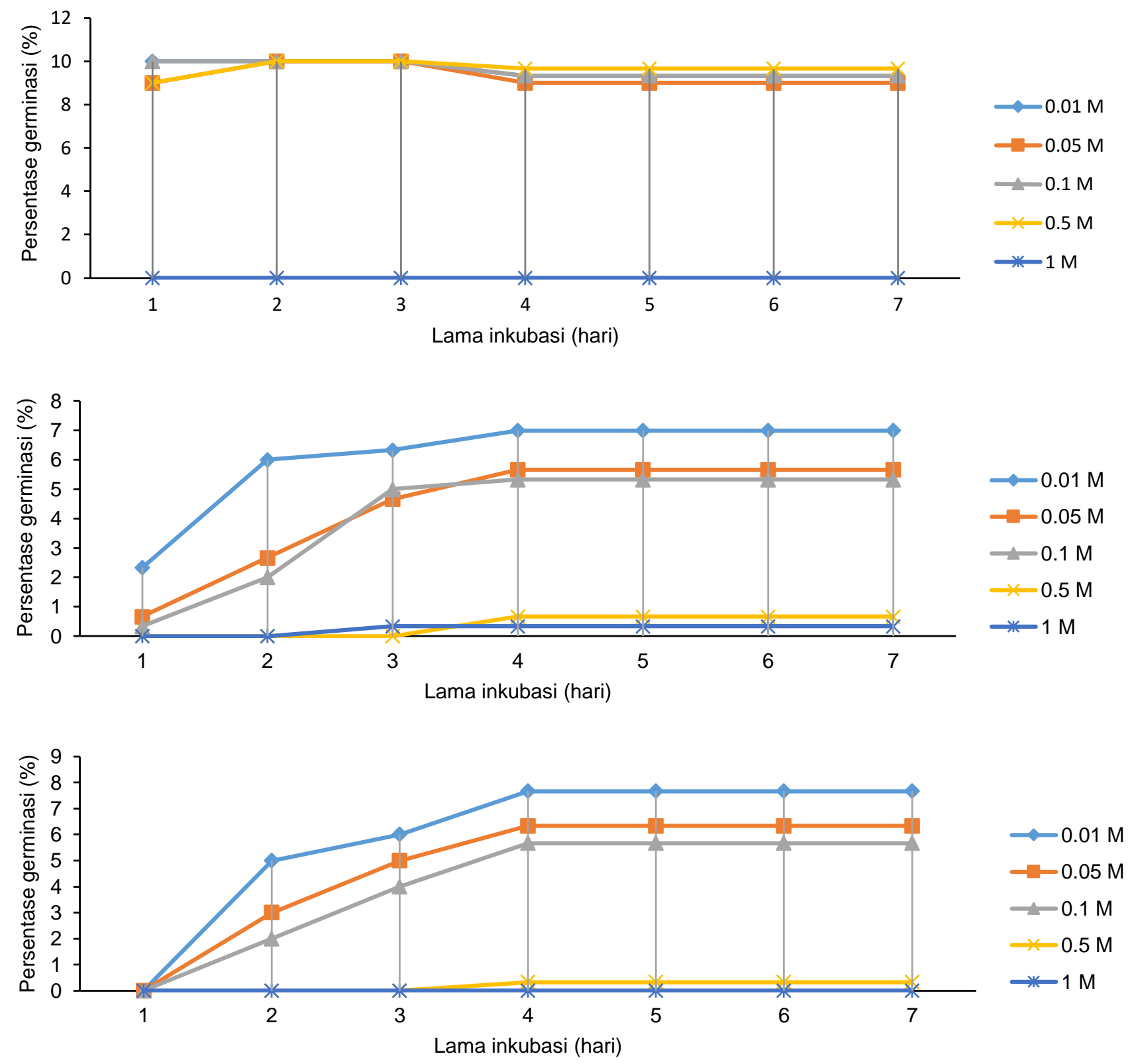

Gambar 3 Persentase germinasi benih (A). kacang hijau (V. radiata), (B) kacang tanah (A. hypogaea), dan jagung ( $Z$. mays) pada berbagai perlakuan konsentrasi $\mathrm{NaCl}$ selama 7 hari pengamatan.

Perlakuan $\mathrm{NaCl}$ konsentrasi $1 \mathrm{M}$ menghasilkan persentase germinasi $0 \%$ pada benih kacang hijau dan jagung (Gambar 3). Hal ini dikarenakan benih mengalami osmosis oleh larutan $\mathrm{NaCl}$. Konsentrasi suatu larutan yang tinggi di luar benih akan berakibat pada penurunan air yang dapat diimbibisi oleh benih, dan dengan pengurangan jumlah air maka laju perkecambahan benih akan semakin terhambat karena perubahan proses metabolisme, disorganisasi membran sel, dan penurunan pembelahan sel (Hasegawa et al. 2020). Sementara itu, hasil maksimal terdapat pada konsentrasi $\mathrm{NaCl} 0,01 \mathrm{M}$, di mana ketiga jenis benih mampu tumbuh dengan baik secara optimal. Dari Tabel 2 diketahui bahwa laju perkecambahan paling cepat adalah pada pemberian $\mathrm{NaCl}$ konsentrasi 0,5 , yaitu sebesar 4,01 hari pada benih kacang hijau; 5,50 hari pada benih kacang tanah; dan 5,50 hari pada benih jagung. Media salin memiliki kandungan garam terlarut, tersusun oleh Natrium $\left(\mathrm{Na}^{+}\right)$ dan Klorida $\left(\mathrm{Cl}^{-}\right)$. Konsentrasi larutan garam yang tinggi dapat merusak dan meracuni benih yang disebabkan oleh perubahan daya osmotik. Kerusakan yang ditimbulkan dapat berupa penghambatan pertumbuhan akibat potensial osmotik tinggi, gangguan metabolisme normal akibat adanya ion $\mathrm{Na}$ yang tinggi, serta penghambatan penyerapan kation esensial lain bagi tanaman (Radić et al. 2013).

Laju perkecambahan dipengaruhi oleh kombinasi antara media yang digunakan dengan pemberian temperatur. Pemberian temperatur berpengaruh pada laju perkecambahan, dan pada Tabel 2 ditunjukkan bahwa laju perkecambahan lebih tinggi pada saat 
pemberian temperatur $30^{\circ} \mathrm{C}$. Benih kacang hijau dan benih jagung memiliki laju perkecambahan sebesar 4,18 dan 5,20. Temperatur merupakan salah satu faktor eksternal yang penting dalam regulasi perkecambahan biji. Temperatur berpengaruh pada kecepatan dan persentase perkecambahan biji, yang secara langsung berperan dalam proses imbibisi serta reaksi biokimia dalam meregulasi metabolisme dalam proses perkecambahan biji (Guo et al. 2020).

Aktivasi enzim sangat berkaitan dengan temperatur. Temperatur yang terlalu tinggi akan mengakibatkan enzim rusak, sedangkan temperatur yang rendah akan membuat enzim tidak aktif. Setiap enzim memiliki temperatur optimum yang berbeda. Pada benih kacang hijau dan jagung, pemberian temperatur $30^{\circ} \mathrm{C}$ lebih optimal dibandingkan dengan pemberian temperatur $35^{\circ} \mathrm{C}$. Hal ini sesuai dengan penelitian yang pernah dilakukan oleh Bahri et al. (2012) yang menyebutkan bahwa untuk aktivasi awal enzim amilase diperlukan temperatur optimum $70^{\circ} \mathrm{C}$ pada benih jagung (Zea mays), dan setelah mencapai kondisi optimum, aktivitas enzim menurun. Penurunan aktivitas enzim terjadi karena temperatur tinggi mengakibatkan struktur enzim berubah sehingga sisi aktif enzim menjadi rusak.

\section{Indeks Kecepatan Perkecambahan}

Hasil nilai indeks kecepatan perkecambahan berdasarkan Tabel 3 dapat diketahui bahwa semakin tinggi konsentrasi $\mathrm{NaCl}$ maka nilai IKP benih semakin rendah. Hal ini disebabkan karena IKP berkaitan dengan kondisi lingkungan yang sesuai dengan perkecambahan benih. Setiap benih memiliki kondisi lingkungan yang berbeda sebagai syarat terjadinya perkecambahan karena setiap jenis benih memiliki anatomi yang berbeda. Benih kacang hijau yang diberikan $\mathrm{NaCl} 0,01 \mathrm{M}$ memiliki IKP 25,42 hari, sedangkan benih jagung dengan pemberian $\mathrm{NaCl} 0,01$ M menghasilkan IKP 10,32 hari. IKP yang dihasilkan setiap jenis benih berbeda walaupun konsentrasi $\mathrm{NaCl}$ sama. Perbedaan respons tersebut dikarenakan benih jagung mempunyai struktur yang lebih keras sehingga dibutuhkan konsentrasi larutan yang lebih tinggi dan waktu imbibisi yang lebih lama untuk mengaktifkan auksin dan giberelin sebagai hormon perkecambahan (Hu et al. 2020).

Kecepatan perkecambahan benih sangat bervariasi, dan hal ini berkaitan dengan kondisi lingkungan pertumbuhan benih, di mana benih akan melakukan perkecambahan yang optimal jika kondisi lingkungan sekitar mendukung untuk terjadi proses perkecambahan. Berkaitan dengan hormon yang ada pada benih tersebut, kondisi lingkungan untuk berkecambah pada setiap jenis benih bervariasi. Beberapa benih dengan temperatur dingin lebih cepat berkecambah, namun beberapa jenis benih justru perkecambahannya terjadi lebih cepat jika terkena temperatur hangat bahkan yang lebih panas. Temperatur merupakan salah satu faktor utama yang memengaruhi kecepatan serta optimasi perkecambahan benih. Pada benih rekalsitran atau benih yang tidak dapat tumbuh dalam lingkungan dengan kandungan air yang sedikit maka temperatur tinggi dan kering akan merusak kemampuan benih untuk tumbuh dan berkecambah, namun pada benih dengan tipe benih ortodok, dapat bertahan bahkan perlakuan dengan temperatur tinggi akan meningkatkan kemampuan berkecambah benih (Pratama et al. 2016). Dalam penelitian ini, suhu $35^{\circ} \mathrm{C}$ dapat meningkatkan nilai IKP untuk ketiga jenis benih yang merupakan benih rekalsitran.

\section{Vigor Benih}

Indeks vigor benih merupakan indikator untuk mengetahui keseragaman dan kecepatan perkecam-

Tabel 2 Laju Perkecambahan benih kacang hijau (V. radiata), kacang tanah ( $A$. hypogaea), dan jagung ( $Z$. mays) pada berbagai perlakuan $\mathrm{NaCl}$ dan temperatur

\begin{tabular}{lcccc}
\hline & \multirow{2}{*}{ Perlakuan } & & \multicolumn{3}{c}{ Laju perkecambahan (hari) } \\
\cline { 3 - 5 } & & Kacang hijau & Kacang tanah & Jagung \\
\hline \multirow{3}{*}{$\mathrm{NaCl}(\mathrm{M})$} & 0,01 & 3,94 & 4,39 & 4,72 \\
& 0,05 & 3,95 & 4,72 & 4,81 \\
& 0,10 & 3,94 & 4,77 & 4,91 \\
\multirow{2}{*}{ Temperatur $\left({ }^{\circ} \mathrm{C}\right)$} & 0,50 & 4,01 & 5,50 & 5,50 \\
& 1,00 & 0,00 & 5,00 & 0,00 \\
\hline
\end{tabular}

Tabel 3 Indeks Kecepatan Perkecambahan benih kacang hijau ( $V$. radiata), kacang tanah ( $A$. hypogaea), dan jagung ( $Z$. mays) pada berbagai perlakuan $\mathrm{Nacl}$ dan temperatur

\begin{tabular}{lrccc}
\hline \multirow{2}{*}{ Perlakuan } & & \multicolumn{3}{c}{ Indeks kecepatan perkecambahan (hari) } \\
\cline { 3 - 5 } & & Kacang hijau & Kacang tanah & Jagung \\
\hline \multirow{3}{*}{$\mathrm{NaCl}(\mathrm{M})$} & 0,01 & 25,42 & 12,76 & 10,32 \\
& 0,05 & 24,17 & 7,86 & 6,48 \\
& 0,10 & 25,17 & 7,05 & 6,64 \\
& 0,50 & 24,68 & 0,51 & 0,26 \\
Temperatur $\left({ }^{\circ} \mathrm{C}\right)$ & 1,00 & 0,00 & 0,36 & 0,00 \\
\hline
\end{tabular}


bahan. Benih dengan vigor tinggi lebih mampu untuk bertahan dan tumbuh dengan baik pada kondisi suboptimum. Selain itu, kelebihan benih yang bervigor tinggi mempunyai kemampuan untuk tumbuh lebih cepat, serta daya simpan yang lebih lama meskipun dalam kondisi yang kurang ideal (Zanzibar \& Pramono 2009). Parameter vigor benih yang diamati dalam penelitian ini adalah indeks vigor (IV) (\%), kecepatan tumbuh (Kct) (\%/etmal), dan keserempakan tumbuh (Kst) (\%). Vigor benih menurun lebih cepat dibandingkan viabilitas. Menurut hasil penelitian Ismattullah (2003) mengenai penyimpanan, vigor benih kedelai kultivar Wilis lebih cepat menurun dibandingkan viabilitas potensial benihnya. Sementara itu, nilai kecepatan tumbuh, benih kedelai lebih cepat menurun dibandingkan daya berkecambahnya. Oleh karena itu, vigor benih sangat dipengaruhi oleh metode penyimpanan dan waktu simpan benih.

\section{Indeks Vigor}

Indeks vigor merupakan pembanding antara jumlah kecambah normal pada hitungan pertama dengan jumlah semua benih yang ditanam. Pengujian indeks vigor dianggap lebih peka dan dapat menginformasikan secara akurat potensi tumbuh di lapang atau lahan dibandingkan dengan pengujian daya kecambah. Kolasinka et al. (2000) menyatakan bahwa persentase kecambah normal pada pengamatan pertama berhubungan erat dengan kemampuan benih berkecambah di lapang dibandingkan dengan persentase kecambah pada akhir pengamatan. Tabel 4 menunjukkan bahwa indeks vigor paling tinggi terdapat pada kacang hijau dengan perlakuan salinitas $\mathrm{NaCl}$ konsentrasi 0,5 M, yaitu sebesar 96,67\%. Konsentrasi $1 \mathrm{M}$ memiliki indeks vigor paling rendah pada ketiga jenis benih. Indeks vigor benih kacang tanah dan kacang hjau menunjukkan bahwa semakin tinggi konsentrasi $\mathrm{NaCl}$, maka semakin rendah nilai Indeks Vigornya. Akan tetapi, pada benih kacang hijau, nilai indeks vigor tertinggi ditemukan pada perlakukan konsentrasi $\mathrm{NaCl}$ 0,5 M. Hal ini menunjukkan bahwa tingkat salinitas dengan konsentrasi kurang dari atau sama dengan $0,5 \mathrm{M}$ tidak berpengaruh langsung pada indeks vigor benih kacang hijau, Pada umumnya, semakin tinggi tingkat salinitas akan menghambat perkecambahan dan menurunkan nilai indeks vigor benih. Peningkatan konsentrasi $\mathrm{NaCl}$ dapat menghambat proses imbibisi benih karena kelarutan garam dapat menurunkan tekanan osmotik sehingga benih tidak dapat menyerap air yang diperlukan untuk pengaktifan enzim yang penting untuk keberlangsungan proses perkecambahan. Salinitas pada media tanam berpengaruh pada proses perkecambahan benih karena salinitas mampu menurunkan potensial air pada media tanam sehingga menghambat penyerapan air oleh benih (Rini et al. 2005).

Selain salinitas, temperatur juga memengaruhi indeks vigor benih melalui mekanisme aktivasi enzim. Temperatur yang terlalu tinggi mengakibatkan enzim terdenaturasi dan proses perkecambahan menjadi terhambat. Hal ini sesuai dengan penelitian yang telah dilakukan bahwa indeks vigor benih kacang hijau, kacang tanah, dan jagung dengan perlakuan temperatur $30^{\circ} \mathrm{C}$ lebih optimal dibandingkan perlakuan temperatur $35^{\circ} \mathrm{C}$.

\section{Keserempakan Tumbuh Benih}

Indikasi vigor benih yang baik adalah ketika benih mampu tumbuh dengan cepat dan seragam. Nilai keserempakan tumbuh benih menunjukkan nilai peubah parameter vigor benih yang menggambarkan potensi benih untuk cepat tumbuh, muncul seragam, dan pengembangan bibit normal dalam berbagai kondisi lapangan (Lesilolo et al. 2013). Salah satu faktor yang dapat memengaruhi benih menjadi tidak mampu tumbuh seragam ialah kondisi lingkungan yang heterogen. Menurut Sadjad (1993), nilai keserempakan tumbuh berkisar antara $40-70 \%$. Apabila nilai keserempakan tumbuh lebih besar dari $70 \%$ maka hal ini mengindikasikan vigor kekuatan tumbuh sangat tinggi, dan jika keserempakan kurang dari 40\% maka hal ini mengindikasikan kelompok benih yang kurang vigor. Keserempakan tumbuh benih yang tinggi mengindikasikan vigor kekuatan tumbuh absolut yang tinggi karena suatu kelompok benih menunjukkan pertumbuhan serempak dan kuat akan memiliki kekuatan tumbuh yang tinggi. Tabel 5 menunjukkan salinitas yang tinggi akan menghambat proses perkecambahan, yang sama halnya dengan indeks vigor. Hasil penelitian menunjukkan bahwa kacang hijau memiliki nilai keserempakan tumbuh paling tinggi dibandingkan dengan kacang tanah dan jagung. Pada perlakuan $\mathrm{NaCl}$ 0,5 M nilai Kst kacang hijau mencapai $96,67 \%$, sedangkan pada kacang tanah dan jagung secara berturut-turut adalah $6,67 \%$ dan $3,33 \%$.

Tabel 4 Indeks vigor benih kacang hijau ( $V$. radiata), kacang tanah ( $A$. hypogaea), dan jagung ( $Z$. mays) pada berbagai perlakuan $\mathrm{NaCl}$ dan temperatur

\begin{tabular}{lcccc}
\hline \multirow{2}{*}{ Perlakuan } & & \multicolumn{3}{c}{ Indeks vigor (\%) } \\
\cline { 3 - 5 } & & Kacang hijau & Kacang tanah & Jagung \\
\hline \multirow{3}{*}{$\mathrm{NaCl}(\mathrm{M})$} & 0,01 & 93,33 & 70,00 & 76,67 \\
& 0,05 & 90,00 & 56,67 & 63,33 \\
& 0,10 & 93,33 & 53,33 & 56,67 \\
& 0,50 & 96,67 & 6,67 & 3,33 \\
Temperatur $\left({ }^{\circ} \mathrm{C}\right)$ & 1,00 & 0,00 & 3,33 & 0,00 \\
\hline
\end{tabular}


Perlakuan salinitas dan suhu pada ketiga benih sangat memengaruhi keserempakan tumbuh benih.

\section{Kecepatan Tumbuh Benih}

Kecepatan tumbuh benih akan berbeda-beda, bergantung pada jenis benihnya. Ada kecenderungan bahwa kecepatan tumbuh benih menurun dengan pertambahan ukuran benih. Menurut Jumini (2006), benih dengan ukuran besar, relatif membutuhkan rentang waktu yang lebih lama untuk berkecambah dibandingkan dengan benih yang berukuran lebih kecil. Hal ini diasumsikan berhubungan dengan luas permukaan biji untuk terjadinya imbibisi dan pengaktifan enzim serta hormon perkecambahan. Pada penelitian ini, biji kacang hijau memiliki kecepatan tumbuh yang paling tinggi dibandingkan dengan kacang tanah dan jagung. Hal ini sesuai, apabila dilihat dari ukuran biji kacang hijau yang lebih kecil dibandingkan dengan kedua biji yang lain.

Tabel 6 menunjukkan bahwa semakin tinggi nilai salinitas dan suhu mengakibatkan semakin turun kecepatan tumbuh benih. Gairola et al. (2011) menyebutkan bahwa spesies yang berbeda memiliki perbedaan toleransi terhadap suhu dan salinitas. Suhu sangat berpengaruh pada kecepatan tumbuh benih kacang hijau, kacang tanah, dan jagung. Pada penelitian ini, suhu optimum untuk perkecambahan biji adalah $30^{\circ} \mathrm{C}$. Perkecambahan merupakan tahap awal dari siklus hidup tumbuhan, yang menentukan di mana dan kapan sebuah tanaman dapat tumbuh secara mandiri. Vigor tanaman dipengaruhi oleh faktor internal dan faktor eksternal biji. Faktor internal meliputi genetik, kemasakan biji, ukuran biji, dan deteriorasi yang berasal dari biji itu sendiri. Sementara faktor eksternal berupa kondisi lingkungan yang memengaruhi, misalnya kerusakan biji, mikroorganisme dan patogen, air, salinitas, dan jenis media tanam (Tsegay \& Gebreslassie 2014).

Salinitas dan temperatur merupakan salah satu faktor abiotik utama yang membatasi pertumbuhan dan produktivitas tanaman. Selain itu, media tanam juga berperan penting dalam perkecambahan biji. Media tanam tidak hanya berperan sebagai tempat untuk tumbuh, melainkan juga sebagai sumber nutrient bagi pertumbuhan tanaman. Penelitian ini menggunakan metode Brick Gravel Test dengan media bata merah sebagai tempat pertumbuhan kecambah (Bhardwaj 2014). Pecahan batu bata merupakan media tanam yang berfungsi untuk melekatkan akar. Semakin kecil ukuran pecahan batu bata tersebut, maka kemampuan daya serap terhadap air maupun unsur hara akan semakin baik. Selain itu, ukuran yang semakin kecil juga akan membuat sirkulasi udara dan kelembapan di sekitar akar tanaman berlangsung lebih baik. Pertumbuhan kecambah selanjutnya membutuhkan media tanam yang menyediakan tidak hanya air, tetapi diperlukan aerasi yang optimal untuk perkembangan akar yang pada akhirnya mendukung perkembangan tajuk. Media bata merah dianggap dapat menghasilkan pertumbuhan tanaman yang baik dengan kemampuannya mengikat air dan bagi perkembangan akar tanaman. Begitu pula dengan media kapas yang memiliki kemampuan menyerap dan mengikat air tinggi sehingga proses perkecambahan dapat berlangsung dengan baik karena imbibisi terjadi secara optimal.

\section{KESIMPULAN}

Perkecambahan merupakan suatu proses yang kompleks dan dipengaruhi oleh berbagai faktor internal dan eksternal benih. Perlakuan temperatur dan

Tabel 5 Keserempakan tumbuh benih kacang hijau (V. radiata), kacang tanah (A. hypogaea), dan jagung (Z. mays) pada berbagai perlakuan $\mathrm{NaCl}$ dan temperatur

\begin{tabular}{lcccc}
\hline \multirow{2}{*}{ Perlakuan } & & \multicolumn{3}{c}{ Keserempakan tumbuh (\%) } \\
\cline { 3 - 5 } & & Kacang hijau & Kacang tanah & Jagung \\
\hline \multirow{3}{*}{$\mathrm{NaCl}(\mathrm{M})$} & 0,01 & 93,33 & 70,00 & 76,67 \\
& 0,05 & 90,00 & 56,67 & 63,33 \\
& 0,10 & 93,33 & 53,33 & 56,67 \\
& 0,50 & 96,67 & 6,67 & 3,33 \\
\multirow{2}{*}{ Temperatur $\left({ }^{\circ} \mathrm{C}\right)$} & 1,00 & 0,00 & 3,33 & 0,00 \\
& 30,00 & 100,00 & 96,67 & 90,00 \\
\end{tabular}

Tabel 6 Kecepatan tumbuh benih kacang hijau ( V. radiata), kacang tanah (A. hypogaea), dan jagung (Z. mays) pada berbagai perlakuan $\mathrm{NaCl}$ dan temperatur

\begin{tabular}{lrccc}
\hline \multirow{2}{*}{ Perlakuan } & & \multicolumn{3}{c}{ Kecepatan tumbuh (\%/etmal) } \\
\cline { 3 - 5 } & 0,01 & Kacang hijau & Kacang tanah & Jagung \\
\hline \multirow{3}{*}{$\mathrm{NaCl}(\mathrm{M})$} & 0,05 & 10,49 & 5,32 & 4,13 \\
& 0,10 & 10,07 & 3,28 & 3,34 \\
& 0,50 & 10,59 & 2,94 & 2,81 \\
& 1,00 & 10,28 & 0,21 & 0,07 \\
Temperatur $\left({ }^{\circ} \mathrm{C}\right)$ & 30,00 & 0,00 & 0,15 & 0,00 \\
\hline
\end{tabular}


salinitas berpengaruh pada kualitas benih kacang hijau ( $V$. radiata), kacang tanah ( $A$. hypogaea), dan jagung (Zea mays) ditinjau dari viabilitas dan vigor benih. Larutan Triphenyl tetrazolium chloride (TTC) efektif digunakan untuk mengetahui viabilitas benih secara cepat dan tepat. Kacang hijau memiliki daya kecambah, laju perkecambahan, Indeks Kecepatan Perkecambahan, Indeks Vigor, keserempakan tumbuh, dan kecepatan tumbuh benih yang paling tinggi dibandingkan benih kacang tanah dan jagung pada semua perlakuan salinitas dan temperatur. Perlakuan temperatur $30^{\circ} \mathrm{C}$ menghasilkan viabilitas dan vigor benih yang paling baik untuk ketiga tanaman uji. Salinitas tinggi dapat menghambat perkecambahan pada semua benih tanaman. Daya kecambah pada ketiga jenis benih semakin menurun seiring dengan peningkatan konsentrasi $\mathrm{NaCl}$.

\section{DAFTAR PUSTAKA}

Bahri S, Mirzan M, Hasan M. 2012. Karakterisasi enzim amilase dari kecambah biji jagung ketan (Zea mays ceratina L.). Jurnal Natural Sciences. 1(1): 132143.

Bhardwaj RL. 2014. Effect of growing media on seed germination and seedling growth of papaya cv. 'Red lady'. African Journal of Plant Science. 8(4): 178184. https://doi.org/10.5897/AJPS11.265

Bouzo C. 2012. Effect of temperature on melon development rate. Agronomy research. 10(1-2): 283. https://doi.org/10.1155/2012/287608

Da costa LO, MB Mc Donald. 2001. Principlesof Seed Science and Technology. New York (US): Burgess Publishing Company. https://doi.org/10.1016/ j.plantsci.2019.110294

Copeland LO, MB Mc Donald. 1976. Principles of Seed Sciences and Technology. Minessota (US): Burgess Publishing Company.

Da Costa CT, Offringa R, Fett-Neto AG. 2019. The role of auxin transporters and receptors in adventitious rooting of Arabidopsis thaliana pre-etiolated flooded seedlings. Plant Science. 290(2020): 110294

Delgado FIC, Giménez LE, Gómez MF, Pedrosa W. 2016. Influence of temperature and salinity on the germination of Limonium tabernense erben from tabernas desert (Almería, SE Spain). Flora Morphology, Distribution, Functional Ecology of Plan. 218: 68-74. https://doi.org/10.1016/ j.flora.2015.12.001

Fatmawati LI, Suharsi TK, Qadir. 2018. Uji tetrazolium pada benih kecipir (Psopocarpus tetragonolobus (L.) DC) sebagai tolok ukur viabilitas. Buletin Agrohoti. 6(2): 231-240. https://doi.org/10.29244/ agrob.v6i2.19093
Gairola KC, Nautiyal AR, Dwivedi AK. 2011. Effect of temperatures and germination media on seed germination of Jatropha curcas Linn. Advances in Bioresearch. 2(2): 66-71.

Grzybowski CRS, Ohlson OC, Silva RCS, Panobianco M. 2012. Viability of barley seeds by the tetrazolium test. Revista Brasiliera de Sementes. 34(1): 47-57. https://doi.org/10.1590/S0101-31222012000100 006

Guan X, Ramaswamy H, Zhang B, Lin B, Hou L, Wang S. 2020. Influence of Moisture content, temperature and heating rate on germination rate of watermelon seeds. Scientia Horticulturae. 272: 2-7. https:// doi.org/10.1016/j.scienta.2020.109528

Guo C, Shen Y, Shi F. 2020. Effect of temperature, light, and storage time on the seed germination of Pinus bungeana Zucc. Ex Endll,: The role of seedcovering layers and abscisic acid changes. Forest. 11(3): 300. https://doi.org/10.3390/f11030300

Hasegawa PM, Bressan RA, Zhu JK, Bohnert HJ. 2000. Plant cellular and molecular responses to hight salinity. Annual Review of Plant Physiology and Plant Molecular Biology. 51(1): 463-499. https://doi.org/10.1146/annurev.arplant.51.1.463

Hasrawati, Mustai K, Dachlan A. 2015. Pengujian viabilitas benih kacang tanah (Arachis hypogaea L.) pada berbagai lama penyimpanan dengan menggunakan uji tetrazolium. Journal of Agrotan. 1(2): 94-107.

Hu J, Zhang F, Gao G, Li H, Wu X. 2020. Auxin-related genes associated with leaf petiole angle at the seedling stage are involved in adaptation to low temperature in Brassica napus. Environmental and Experimental Botany. 1-38. https://doi.org/ 10.1016/j.envexpbot.2020.104308

International Seed Testing Association (ISTA). 2010. Seed Science and Technology. International rules for seed testing. Zurich $(\mathrm{CH})$ : International Seed Testing Association.

Ismatullah. 2003. Studi penciri mutu benih kedelai (Glycine max L.) varietas wilis selama masa penyimpanan. [Skripsi]. Bogor (ID): Institut Pertanian Bogor.

Jacob PT, Siddiqui SA, Rathore MS. 2020. Seed germination, seedling growth and seedling development associated physiochemical changes in Salicornia brachiata (Roxb.) under salinity and osmotic stress. Aquatic Botany. (166): 1-12. https://doi.org/10.1016/j.aquabot.2020.103272

Jumini. 2006. Viabilitas benih sebagai indikator tingkat pencemaran lingkungan. Jurnal Floratek. 2: 12-18

Kolasinka K, Szyrmer J, Dul S. 2000. Relationship between laboratory seed quality test and field emergence of common bean seed. Crop Science. 
(40): 470-475. https://doi.org/10.2135/cropsci 2000.402470x

Lesilolo MK, Riry J, Matatula EA. 2013. Pengujian viabilitas dan vigor benih beberapa jenis tanaman yang beredar di pasaran kota ambon. Agrologia. 2(1): 1-9. https://doi.org/10.30598/a.v2i1.272

Moriya LM, Neto NBM, Marks TM, Castilho C Custodio. 2015. Seed vigour better to be asessed by physiological markers rather than expression of antioxidant enzymes in the common bean (Phaseolus vulgaris L.). Australian Journal of Crop Science. 9(1): 30-40.

Neto JBF, Krzyzanowski. 2019. Tetrazolium: an important test for physiology seed quality evaluation. Journal of Seed Science. 41(3): 359366. $\quad$ https://doi.org/10.1590/2317-1545v41n 3223104

Nisa M, Khan M, Weber DJ. 2007. Dormancy, germination and viability of Salsola imbricata seeds in relation to light, temperature and salinity. Seed Science and Technology. 35: 595-606. https:// doi.org/10.15258/sst.2007.35.3.07

Pratama ME, Fatihah B, Darmayanti AS, Irawanto R. 2016. Kemampuan viabilitas benih yang tersimpan dalam freezer di kebun raya purwodadi: Prosiding Semnas Biologi Univ Negeri Malang, Malang (ID): 30 Desember 2016

Radic S, Štefanić PP, Lepeduš H, Roje V, PevalekKozlina B. 2013. Salt tolerance of centaurea Ragusina $\mathrm{L}$. is associated with efficient osmotic adjustment and increased antioxidative capacity. Environmental and Experimental Botany. 87: 3948. $\quad$ https://doi.org/10.1016/j.envexpbot.2012. 11.002

Raganatha IN, Raka IGN, Siadi IK. 2004. Daya simpan benih tomat (Lycopersium esculentum mill.) hasil beberapa teknik ekstrasi. E-jurnal Agroteknologi Tropika. 3(3): 183-190.
Rini DS, Mustikowe, Surtiningsih. 2005. Respon perkecambahan benih sorgum (Sorgum bicolor L. Moerch) terhadap perlakuan osmoconditioning dalam mengatasi cekaman salinitas. Jurnal Biologi. 7(6): 307-313.

Sadjad S. 1993. Dari Benih Kepada Benih. Jakarta (ID): PT Grasindo.

Satya II, Haryati, Simanungkalit T. 2005. Pengaruh perendaman asam sulfat $\left(\mathrm{H}_{2} \mathrm{SO}_{4}\right)$ terhadap viabilitas benih delima (Punica granatum L.). Jurnal Agroteknologi Universitas Sumatera Utara. 3(4): 1375-1380.

Subantoro, Prabowo. 2013. Pengkajian viabilitas benih dengan tetrazolium test pada jagung dan kedelai. Jurnal IImu-IImu Pertanian. 9(2): 1-8.

Sutopo L. 1988. Teknologi Benih. Jakarta (ID): CV Rajawali.

Tatipata A, Yudono P, Purwantoro A, Mangoendidjojo W. 2004. Kajian aspek fisiologi dan biokimia deteriorasi benih kedelai dalam penyimpanan. IImu Pertanian. 11(2): 76-87.

Tefa A. 2017. Uji viabilitas dan vigor benih padi (Oryza sativa L.) selama penyimpanan pada tingkat kadar air yang berbeda. Savana Cendana. 2(3): 48-50. https://doi.org/10.32938/sc.v2i03.210

Tsegay BA, Gebreslassie BG. 2014. The effect of salinity $(\mathrm{NaCl})$ on germination and early seedling growth of Lathyrus sativus and Pisum sativum var. abyssinicum. African Journal of Plant Science. 8(5): 225-231. https://doi.org/10.5897/AJPS2014. 1176

Zanzibar M, Pramono AA. 2009. Penentuan vigor kekuatan tumbuh dan vigor daya simpan relatif benih merbau, akor dan mindi. Jurnal Penelitian Hutan Tanaman. 6(3): 145-155. https://doi.org/ 10.20886/jpht.2009.6.3.145-155 